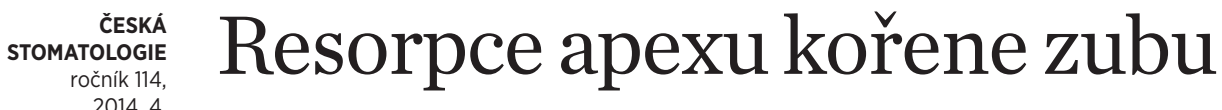 při ortodontické intruzi malou a velkou silou
}

(Původní práce - klinická prospektivní studie)

\section{Resorption of Root Apex during Orthodontic Tooth Intrusion Using Light and Heavy Forces}

(Original Article - Clinical Prospective Study)

\section{Marek I.', Kučera J.. ${ }^{1,}$, Kamínek M.'}

'Klinika zubního lékařství LF UP a FN, Olomouc

${ }^{2}$ Ústav klinické a experimentální stomatologie 1. LF UK a VFN, Praha

Věnováno prof. MUDr. Janu Kilianovi, DrSc., k významnému životnímu jubileu

\begin{abstract}
SOUHRN
Úvod a cíl studie: Cílem této prospektivní studie bylo zjistit, jaká je závislost míry zevní resorpce apexu kořene na velikosti aplikované ortodontické síly během intruzního pohybu zubu. Současně byla sledována závislost resorpce na rozsahu intruze.

Metody: Do souboru studie bylo zahrnuto celkem 34 premolárů u 17 pacientů. Na kontralaterální zuby jednoho jedince bylo působeno malou intruzní silou - $50 \mathrm{cN}$ (light force, LF) a velkou intruzní silou - 150 cN (heavy force, HF). Sledované parametry byly posuzovány v čase před experimentem (TO) a po šestiměsíční intruzi zubů (T1). Následně pak byly lineární rozměry zubu měřeny na extrahovaných premolárech in situ. Hodnotily celkem dva klinické parametry, čtyři parametry na Cone Beam CT a dva parametry na extrahovaných zubech. Rozdíly mezi skupinami byly vyhodnoceny statisticky dvouvýběrovým t-testem.

Výsledky: Velikost intruze byla signifikantně větší při aktivaci velkou silou, a to téměř trojnásobná ve srovnání s aktivací malou silou (4,64 mm oproti 1,53 mm). V obou skupinách došlo ke zkrácení délky zubu vestibulárně, o 0,31 mm ve skupině LF a o 0,67 mm ve skupině HF. Rozdíl mezi oběma skupinami však nebyl signifikantní ( $p=0,06$ ). U obou skupin jsme zaznamenali signifikantní zkrácení délky zubu palatinálně o $0,49 \mathrm{~mm}$ a $0,75 \mathrm{~mm}$, nicméně ani zde nebyl rozdíl mezi skupinami signifikantní $(p=0,37)$. Při porovnání změn délky kořenů v obou skupinách bylo nalezeno také signifikantní zkrácení délky vestibulárního kořene o 0,44 $\mathrm{mm}$ a 0,74 mm ( $p=0,038$ a $p=0,016)$. Signifikantní rozdíl mezi skupinami však nalezen nebyl $(p=0,18)$.

Závěry: Velké intruzní síly způsobily ve srovnání s malými intruzními silami větší rozsah intruze. $V$ průběhu aplikace intruzní síly velikosti $50 \mathrm{cN}$ a $150 \mathrm{cN}$ došlo k signifikantnímu zkrácení délky kořenů zubů. Nebyla však prokázána závislost apikální resorpce kořenového hrotu na velikosti aplikované intruzní síly ani na rozsahu intruzního pohybu.
\end{abstract}

Klíčová slova: intruze - malá a velká intruzní síla - resorpce apexu kořene - premolár

\section{SUMMARY}

Introduction, aim: The aim of this prospective study was to find a relationship between the external apical resorption and magnitude of orthodontic force during tooth intrusion. Relationship between the amount of intrusion and the extent of root resorption was investigated as well.

Methods: The sample included 34 premolars in 17 patients. The light force (LF - $50 \mathrm{cN}$ ) and heavy intrusion force (HF - $150 \mathrm{cN}$ ) were applied on contra-lateral teeth. The measurements were performed 
at time before treatment (TO) and after six-month intrusion (T1). The measurements were registered also on the extracted premolars at the end of experiment. Two clinical parameters, four Cone Beam CT parameters and two parameters on extracted teeth were evaluated. The differences were statistically processed with two-sample t-test.

Results: The extent of intrusion was significantly greater during heavy force activation; it was almost three times higher in comparison with light force (4.64 mm compared to $1.53 \mathrm{~mm}$ ). The tooth was shortened at vestibular site in both groups ( $0.31 \mathrm{~mm}$ in LF and $0.67 \mathrm{~mm}$ in HF). However, the difference between both groups was not statistically significant $(p=0.06)$. The significantly shortened tooth was at palatal site in both groups $(0.49 \mathrm{~mm}$ and $0.75 \mathrm{~mm})$ and the difference was also not significant $(p=0.37)$. In comparison of root lengths, they were significantly shorter at vestibular site $(0.49 \mathrm{~mm}$ and $0.75 \mathrm{~mm})$, but the difference between groups was not significant $(p=0.18)$.

Conclusion: Heavy forces lead to a more extensive intrusion in comparison with light forces. Significant root length shortening occurs after the intrusion with both $50 \mathrm{cN}$ and $150 \mathrm{cN}$ force. The relationship between the amount of intrusion force or the extent of intrusion and the apical root resorption was not confirmed.

Keywords: intrusion - light and heavy intrusion force - apical root resorption - premolar

\section{ÚVOD}

Resorpce kořenů je definována bud' jako fyziologický, nebo patologický proces vedoucí ke ztrátě tvrdých zubních tkání. Etiologické faktory u resorpce kořenů stálých zubů jsou často nejasné. V současné době víme, že existují faktory, které ovlivňují resorpci zcela zásadně. Tímto faktorem je především genetická predispozice [2]. Nicméně velikost resorpce apexu kořene je ovlivnitelná i mnoha mechanickými faktory. Intruzní pohyb zubu je, vedle torzního pohybu, nejrizikovějším zubním pohybem podílejícím se na vzniku resorpce apexu kořene. Mnoho studií uvádí intruzní pohyb zubu a velikost síly jako zásadní faktory ovlivňující velikost resorpce kořene $[5,13$, $15,22,23,30,33,34,37,38,40,42-45,49$, 51]. Cílem této studie bylo zhodnotit účinek malých a velkých intruzních sil na rozsah apikální resorpce kořenového hrotu a potvrdit, nebo naopak vyvrátit hypotézu, že velké intruzní síly způsobují ve srovnání s malými silami resorpce většího rozsahu.

\section{MATERIÁL A METODIKA}

V prospektivní studii bylo hodnoceno celkem 34 zubů u 17 jedinců (10 žen, 7 mužů; průměrný věk 15 let a 10 měsíců), kteří splňovali následující kritéria zařazení do souboru experimentu.

1. Premoláry byly přítomny u jedincư, u nichž bylo indikováno Cone Beam CT (CBCT) vyšetření z jiných léčebných důvodů (retence zubů, transpozice, ankylóza zubů).
2. V léčebném postupu byla plánována extrakce dvou premolárů v horní, resp. i dolní čelisti.

3. Byly hodnoceny pouze vitální premoláry s dokončeným vývojem kořene, bez amalgamových výplní nebo protetického ošetření.

4. U všech jedinců existovala kompletní dokumentace na počátku léčby - studijní modely, kefalometrický snímek, klinická fotografie a ortopantomogram.

5. Cíl studie, její průběh, potenciální rizika a nevýhody (např. prodloužení léčby, větší radiační zátěž či větší počet návštěv) byly všem pacientům podrobně vysvětleny a byl získán jejich informovaný souhlas.

Zuby byly rozděleny do dvou skupin podle velikosti použité síly na skupinu s malou silou (light force - LF), kde byla použita síla 50 cN (g) a na skupinu s velkou silou (high force - HF), v níž byla použita síla 150 cN (g). Velká i malá síla byly aplikovány na kontralaterální premoláry u každého jedince s použitím box kličky podle Burstona [6] z drátu 0,018 $\times 0,025$ " Beta titanium 3 (CNA, OrthoOrganizer, USA). Pravý premolár byl vždy zatížen silou $50 \mathrm{cN}$ zatímco levý premolár vždy silou 150 cN. Aparát se skládal z molárových kroužků (Epic, OrthoOrganizer, USA) na prvním moláru a zámku na premoláru (0,018 $\times$ 0,025" drážka, MediumTwin, OrthoOrganizer, USA). Kotvení molárů, z důvodu eliminace jejich meziálního sklonu, který vzniká jako následek momentu síly, bylo zajištěno palatinálním obloukem z oceli síly $0,9 \mathrm{~mm}$. Mechanika intruze box kličkou podle Burstona byla zvolena proto, že aktivace ve dvou bodech, přechodu horizontální části kličky ve vertikální, umožňuje dosáhnout intruzní aktiva- 
ČESKÁ STOMATOLOGIE ročník 114, 2014, 4, s. $94-102$

ce tak, že se vyvarujeme sklonu kořene premoláru meziálně či distálně. Kontrolou nám je paralelní průběh horizontálního raménka s drážkou zámku, kam bude raménko kličky fixováno. Při intruzi zubu však vzniká moment síly, který se projeví vestibulárním sklonem korunky zubu (obr. 1). Proto je nutné vložit do box kličky preaktivaci orálně, která zasahuje na palatinální hrbolek premoláru. Celková doba intruze byla stanovena na šest měsíců, během kterých byly aktivace pravidelně opakovány po 30 dnech. Aplikovaná síla se měřila pomocí siloměru (Dentaurum, Ispringen, Německo). Kontinuální působení síly nebylo v průběhu jednoho měsíce mezi aktivacemi kontrolováno. Bylo hodnoceno celkem šest parametrů, dva klinické a čtyři parametry na CBCT, a to před začátkem intruze (T0) a po jejím ukončení (T1). Dále byly hodnoceny také dva parametry na extrahovaných zubech. Během intruze byl $\mathrm{u}$ jedinců velmi přísně kontrolován stav hygieny. Klinické parametry byly hodnoceny na sádrových modelech a in situ. Všechna měření byla hodnocena jedním lékařem vizuálně na $\mathrm{CBCT}$ skenech (Planmeca ProMax 3D, Planmeca, Finsko) s FOV $8 \times 8 \mathrm{~cm}$, velikostí voxelů $100 \mu \mathrm{m} v$ řezech po $0,5 \mathrm{~mm}$.

\section{Měřené parametry na CBCT řezech:}

$\mathrm{Na}$ CBCT řezech byly hodnoceny tyto parametry (obr. 2):

TLB (délka zubu vestibulárně): vzdálenost mezi nejvyšším bodem vestibulárního hrbolku k vrcholu apexu vestibulárního kořene;

TLP (délka zubu palatinálně): vzdálenost mezi nejvyšším bodem palatinálního hrbolku k vrcholu apexu palatinálního kořene;

CLB (délka korunky vestibulárně): vzdálenost nejvyššího bodu hrbolku vestibulárního k cemento-sklovinné hranici v dlouhé ose zubu;

RLB (délka vestibulárního kořene): vzdálenost mezi cemento-sklovinnou hranicí vestibulárního kořene a vrcholem apexu vestibulárního kořene v dlouhé ose zubu).

Jako bod měření na cemento-sklovinné hranici byl stanoven bod nejnižší konkavity v místě přechodu skloviny na cement kořene. CBCT parametry byly

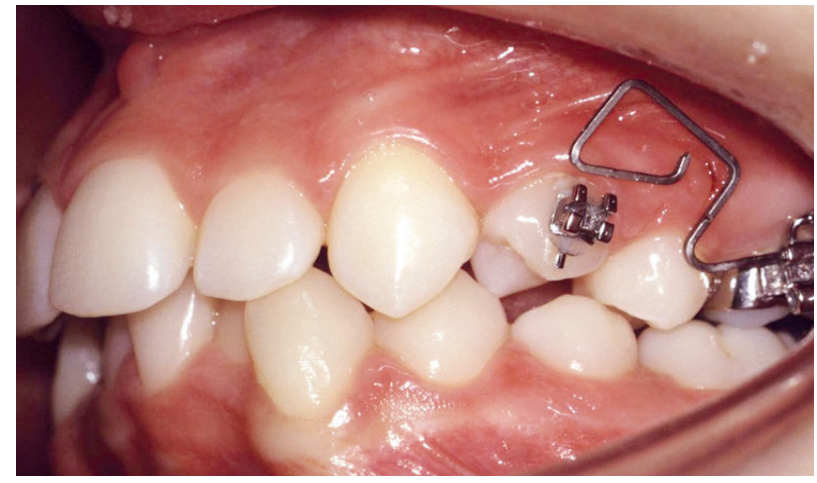

Obr. 1 Aktivace intruzní mechaniky: klička Box CNA byla použita $\mathrm{k}$ intruzi premolárů. Použitá síla byla měřena siloměrem.

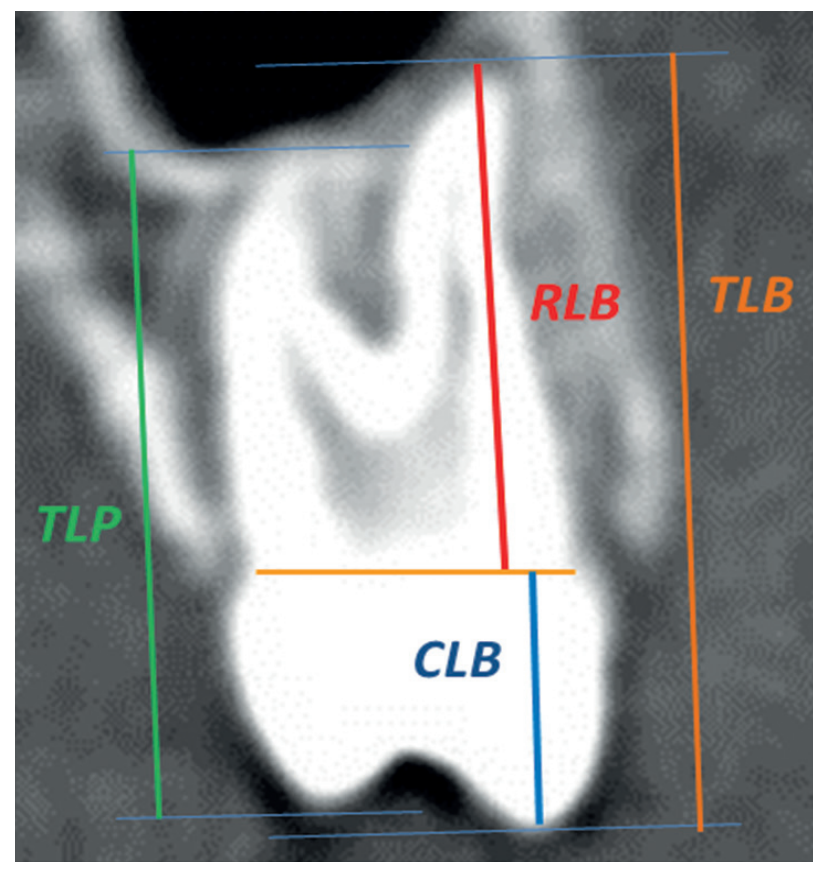

Obr. 2 Měření na CBCT: TLB, TLP (tooth length buccal/palatal - délka zubu bukálně/palatinálně) - vzdálenost mezi apexem kořene a nejvyšším bodem bukálního nebo palatinálního hrbolku. RLB (root length buccal - délka kořene bukálně) - vzdálenost mezi apexem kořene a cemento-sklovinnou hranicí na bukální straně, CLB (crown length buccal - délka korunky bukálně) - vzdálenost mezi nejvyšším bodem bukálního hrbolku a cemento-sklovinnou hranicí na bukální straně.

Tab. 1 Průměrné rozdíly délky zubu měřené na $\mathrm{CBCT}$ a na extrahovaném zubu

\begin{tabular}{|l|c|c|c|c|c|c|}
\hline \multirow{2}{*}{ Rozměr } & \multicolumn{3}{|c|}{ LF (malé silly) } & \multicolumn{3}{c|}{ HF (velké síly) } \\
\cline { 2 - 7 } & Rozdíl & SD & Sig. & Rozdíl & SD & Sig. \\
\hline TLB & $-0,02$ & 0,52 & 0,82 & 0,13 & 0,64 & 0,43 \\
\hline TLP & 0,15 & 0,60 & 0,32 & 0,23 & 0,56 & 0,10 \\
\hline
\end{tabular}

SD - směrodatná odchylka, Sig. - dvouvýběrový t-test 
měřeny pomocí $X$ Vision-CD software (verze 2.5.7., ViDiS company, Siemens, Německo). Řezy byly orientovány v dlouhé ose zubu (koronární rovině) tak, aby vždy protínaly oba hrbolky a hrot kořene intrudovaného premoláru.

Po ukončení intruze byly premoláry extrahovány. Pacient byl odeslán s nádobkou pro uchování zubu na extrakci premolárů ke svému praktickému zubnímu lékaři. Podmínkou pro zařazení do výzkumné skupiny bylo, aby při extrakci nedošlo k fraktuře apexu kořene či celého kořene. Zub byl uschován po bazálním mechanickém očištění měkkých tkání $v$ roztoku formaldehydu. Na extrahovaných zubech byl pak posuvným měřítkem také změřen rozměr TLP a TLB. Rozdíly mezi hodnotami stanovenými měřením na $\mathrm{CBCT}$ a na extrahovaných zubech jsou uvedeny $\mathrm{v}$ tabulce 1.

Na sádrových modelech byly posuzovány následující klinické parametry:

occ (distance from occlusion; míra intruze) vzdálenost mezi bukálním hrbolkem intrudovaného premoláru na kolmici k okluzní rovině tvořenou spojnicí hrbolků sousedních zubů, měřeno na modelech $\mathrm{s}$ přesností $0,1 \mathrm{~mm}$ pomocí digitálního posuvného měřítka.

CC (clinical crown length; délka klinické korunky) - vzdálenost mezi bukálním hrbolkem intrudovaného premoláru a gingivální hranicí, měřeno na modelech s přesností $0,1 \mathrm{~mm}$ pomocí digitálního posuvného měřítka.

\section{Statistické zpracování:}

Na základě efektivní velikosti relevantní proměnné při $\alpha=0,05$ (TLB - délka zubu vestibulárně) byl učiněn předpoklad síly studie s počtem 17 subjektů v každé skupině. Síla studie přesahovala 0,90. Získaná data byla nejprve zpracována metodami popisné statistiky (tab. 2). Pomocí Shapirova-Wilkova testu byla ověřena normalita distribuce dat v obou skupinách. Následně byly párovým t-testem zhodnoceny změny v jednotlivých skupinách (tab. 2), a poté také pomocí dvouvýběrového t-testu mezi oběma skupinami (tab. 3). Statistické zpracování probíhalo v programu SPSS (Statistical Package for the Social Sciences, verze 14). Všechny testy probíhaly na hladině významnosti $\mathrm{p}<0,05$. Výsledky jsou v tabulkách značeny následujícím zpưsobem: ${ }^{* * *} \mathrm{p}<0,001$, ${ }^{* *} \mathrm{p}<0,01,{ }^{*} \mathrm{p}<0,05$. Jeden měsíc po posledním měření bylo měření opakováno na dvaceti náhodně vybraných zubech a byla určena chyba měření pomocí Dahlbergovy formule [11]. Chyba měření pro CBCT parametry byla průměrně $0,19 \mathrm{~mm}$.

\section{VÝSLEDKY}

Hodnoty celkové délky zubu vestibulárně (TLB) i palatinálně (TLP) měřené na $\mathrm{CBCT}$ řezech a shodné parametry měřené na extrahovaných zubech ve skupině s malou i velkou silou vykazují jen malé rozdíly. Ve skupině s malou silou (LF) byl nalezen rozdíl $0,02 \mathrm{~mm}$ pro délku zubu vestibulárně (TLB) a $0,15 \mathrm{~mm}$ pro délku zubu palatinálně. Rozdíl mezi oběma hodnotami není statisticky signifikantní $(\mathrm{p}=0,82$ a $\mathrm{p}=0,32)$. Obdobné rozdíly byly nalezeny i u skupiny s velkou silou; $0,13 \mathrm{~mm}$ pro TLB $(\mathrm{p}=0,43)$ a $0,23 \mathrm{~mm}$ pro TLP $(\mathrm{p}=0,10)$ (viz tab. 1 ).

Měřené klinické a $\mathrm{CBCT}$ parametry a jejich změny u malých a velkých sil, podobně jako rozdíly mezi oběma skupinami, jsou uvedeny v tabulce (viz tab.

Tab. 2 Měřené parametry a jejich změny během léčby u malých a velkých sil

\begin{tabular}{|c|c|c|c|c|c|c|c|c|c|c|c|c|}
\hline \multirow{3}{*}{ Rozměr } & \multicolumn{4}{|c|}{ LF } & & & \multicolumn{4}{|c|}{ HF } & & \\
\hline & \multicolumn{2}{|c|}{ TO } & \multicolumn{2}{|c|}{$\mathrm{T} 1$} & \multirow[b]{2}{*}{ Dif. } & \multirow[b]{2}{*}{$p$} & \multicolumn{2}{|c|}{ TO } & \multicolumn{2}{|c|}{$\mathrm{T} 1$} & \multirow[b]{2}{*}{ Dif. } & \multirow[b]{2}{*}{$p$} \\
\hline & Mean & SD & Mean & SD & & & Mean & SD & Mean & SD & & \\
\hline TLB & 21,29 & 1,23 & 20,99 & 1,38 & $-0,31$ & 0,61 & 21,21 & 1,59 & 20,54 & 1,84 & $-0,67$ & 0,003 \\
\hline TLP & 20,05 & 1,47 & 19,56 & 1,69 & $-0,49$ & 0,01 & 19,65 & 1,59 & 18,89 & 1,90 & $-0,75$ & 0,007 \\
\hline RLB & 13,47 & 1,25 & 13,03 & 1,37 & $-0,44$ & 0,038 & 13,50 & 1,48 & 12,76 & 1,76 & $-0,74$ & 0,016 \\
\hline CLB & 8,06 & 0,96 & 8,04 & 0,92 & 0,02 & 0,86 & 7,82 & 0,89 & 7,75 & 0,77 & 0,06 & 0,57 \\
\hline OCC & 0,00 & 0,00 & 1,69 & 0,57 & 1,69 & 0,0001 & 0,00 & 0,00 & 4,86 & 1,47 & 4,86 & 0,0001 \\
\hline CC & 7,22 & 0,76 & 6,48 & 0,51 & $-0,74$ & 0,0004 & 7,13 & 1,02 & 6,06 & 1,09 & $-1,07$ & 0,00004 \\
\hline
\end{tabular}

TO - začátek léčby, T1 - konec léčby, Mean - průměr, SD - směrodatná odchylka, Dif. - změna během léčby, p - párový t-test, signifikantní výsledek $p<0,05$ 
Tab. 3. Rozdíly parametrů ve skupinách malých a velkých si

\begin{tabular}{|l|c|c|c|c|}
\hline Rozměr & LF & HF & p & Sig. \\
\hline TLB & $-0,31$ & $-0,67$ & 0,06 & NS \\
\hline TLP & $-0,49$ & $-0,75$ & 0,37 & NS \\
\hline RLB & $-0,44$ & $-0,74$ & 0,18 & NS \\
\hline CLB & 0,02 & 0,06 & 0,14 & NS \\
\hline OCC & 1,69 & 4,86 & $\mathbf{0 , 0 0 0 1}$ & $* * *$ \\
\hline CC & $-0,74$ & $-1,07$ & 0,21 & NS \\
\hline
\end{tabular}

p- dvouvýběrový t-test, signifikantní výsledek p<0,05, ${ }^{* * *} p<0,001$, NS - nesignifikantní

2 a 3). Byl nalezen signifikantní rozdíl ( $p=0,0001)$ mezi oběma skupinami pro velikost intruze (OCC). Ve skupině s velkou silou ( $\mathrm{HF}, 150 \mathrm{cN}$ ) byla zaznamenána intruze 4,64 mm, intruze ve skupině s malou silou (LF, $50 \mathrm{cN}$ ) dosáhla pouze hodnoty 1,53 $\mathrm{mm}$. U obou skupin také došlo při intruzi k signifikantnímu zkrácení délky klinické korunky (CC) o 0,74 mm (LF) a 1,07 mm (HF), nicméně mezi oběma skupinami rozdíl nebyl signifikantní.

Při působení malou silou došlo ke zkrácení délky zubu vestibulárně (TLB) o $0,31 \mathrm{~mm}$, což není statisticky signifikantní rozdíl. Signifikantní rozdíl byl však nalezen při použití velké síly, kde došlo ke zkrácení o 0,67 mm. Avšak rozdíl mezi oběma skupinami není statisticky signifikantní $(\mathrm{p}=0,06)$. Délka zubu palatinálně se signifikantně zkrátila $\mathrm{v}$ obou skupinách; ve skupině s malou silou o $0,49 \mathrm{~mm}$ a ve skupině s velkou silou o $0,75 \mathrm{~mm}(\mathrm{p}=0,01 \mathrm{a} \mathrm{p}=0,007)$, ale rozdíl mezi oběma skupinami nalezen nebyl $(\mathrm{p}=0,37)$. Zaznamenali jsme také signifikantní zkrácení vestibulárního kořene u obou skupin; 0,44 mm u LF a 0,74 mm u skupiny HF. Stejně jako u všech ostatních parametrů však rozdíl mezi skupinami nebyl signifikantní. Podle očekávání zůstala délka korunky vestibulárně (CLB) beze změn u obou zkoumaných skupin s průměrnými změnami $0,02 \mathrm{~mm}$ (LF) resp. 0,06 $\mathrm{mm}(\mathrm{HF})$.

\section{DISKUSE}

Cílem této studie bylo porovnat vliv malých a velkých intruzních sil, 50 a $150 \mathrm{cN}$, na resorpci apexu kořenového hrotu. Chtěli jsme potvrdit, nebo naopak vyvrátit hypotézu, že velké síly zpưsobují také větší resorpci kořenového hrotu. Změny v délce zubů a kořenů byly hodnoceny po šest měsíců trvající intruzi na CBCT a na extrahovaných zubech.

Výzkumná perioda pro každý zub byla stanovena na dobu šesti měsíců. Tak dlouhý interval byl zvolen záměrně, a to $z$ několika důvodů. Především jsme se chtěli odlišit od ostatních světových studií zabývajících se stejným tématem $[1,4,8,10,12,19,21,22$, $35,39,50]$. U většiny z těchto prací bylo pưsobení intruzní síly na zub přibližně 4-8 týdnů. Za tak krátkou dobu aplikace ortodontické síly lze nalézt resorpci kořene jen histologicky, a to $\mathrm{v}$ podobě resorpčních lakun různé velikosti a charakteru. Tato časová perioda navíc neodpovídá reálné potřebě obvyklých klinických situací. Domníváme se, že doba trvání našeho experimentu je bliže reálné klinické situaci, ve které je nutné dosáhnout dostatečné intruze např. supraokludovaných zubů. Bylo pro nás také důležité prokázat vliv velikosti intruzní síly na potenciálně klinicky významnou resorpci, neboli na resorpci zjistitelnou nejen mikroskopicky, ale i makroskopicky viditelnou na rentgenovém snímku po ortodontické léčbě, která zřídkakdy trvá méně než šest měsíců. U každého pacienta jsme na jedné straně aplikovali intruzní sílu $50 \mathrm{cN}$ (skupina LF) a druhostranně 150 cN (skupina HF). Tímto designem studie jsme se odlišili od zahraničních studií zabývajících se podobnou tematikou. V nich se používá jako fyziologická intruzní síla (light force) na první horní premolár 25 cN a jako srovnávací velká síla (heavy force) $250 \mathrm{cN}$ [8, 18, 35, 44]. Toto rozpětí je podle našeho názoru př́liš velké, a to díky oběma hodnotám. Síla 15-25 cN na jednokořenový zub je mnohdy uváděna jako fyziologická intruzní síla [24, 47]. Obdobně jako zahraniční studie jsme zařadili do souboru horní první premoláry, tedy zuby prakticky vždy dvoukořenové. Aplikovaná fyziologická síla by tedy měla být 50 cN. Při stanovení hodnoty velké síly bychom měli uvažovat o silách, které může ortodontista reálně technicky aplikovat během léčby pacienta, at' už ve snaze o zrychlení léčby, nebo $z$ pouhé nepozornosti. Otázka by měla znít, zda ortodontista aplikací nadměrné síly může opravdu na jedné straně pohyb zubu urychlit, zda tím však na druhé straně zároveň nezpůsobí větší resorpci apexu kořene. Síla $250 \mathrm{cN}$ používaná v některých zahraničních studiích je 
natolik velká, že jednak lze takto aktivovaný oblouk velice těžko vložit do drážky zámku, jednak je pro pacienta dosti bolestivá. Námi zvolená síla $150 \mathrm{cN}$ oproti tomu je snadno aplikovatelná a pro pacienta je ještě snesitelná.

V odborné literatuře jsou desítky až stovky odborných prací, které se zabývají tématem resorpce apexu kořene, nicméně ve svých závěrech se často rozcházející. V jednom se však všechna odborná sdělení shodují - a to v konstatování, že vznik resorpce apexu kořene během ortodontické léčby je běžným jevem. V dalších tvrzeních již tak jednoznačná shoda neexistuje. Problémem je již samotná definice pojmu zevní resorpce apexu kořene (external apical root resorption - EARR). Zatímco na začátku rentgenologického sledování EARR se za resorpci považovala ztráta apexu kořene v rozsahu několika milimetrů, dnešní metody dokážou odhalit resorpční lakuny v řádech mikrometrů.

Nelze úplně souhlasit s dosti častým tvrzením, že apikální resorpce kořene jsou vážným iatrogenním problémem spojeným s ortodontickou léčbou. Drtivá většina resorpcí vzniklých během ortodontické léčby není klinicky významná a nemá vliv na dlouhodobou prognózu postižených zubů. Konstatování, že resorpce jsou vážným iatrogenním problémem, můžeme brát jako pravdivé až u resorpcí značného rozsahu, které vedou k zásadnímu zkrácení kořene. Tyto resorpce jsou však vzácné a vyskytují se u 3-5 \% pacientů [3]. Můžeme je pozorovat především u pacientů $\mathrm{s}$ individuální predispozicí k resorpcím, které jsou většinou na genetickém podkladě [2]. Obecně se však předpokládá, že v případě resorpcí apexu kořene, vzniklých během ortodontické léčby, jde o výsledek kombinace biologické variability, individuálních reakcí a působení mechanických sil [14, 32, 37, 41]. Resorpční krátery se objevují už při použití nízkých sil, případně i bez ortodontické léčby, což znamená, že resorpce kořenů mohou být běžně se vyskytujícím fyziologickým fenoménem [29, 31, 42, 47, 48]. Obecně se autoři shodují na tom, že existují rizikové faktory a vztahy, jejichž př́itomnost v kombinaci s ortodontickou léčbou mưže ovlivnit vznik a rozsah zevních resorpcí $[15,23,30,33$, 40, 43-45, 48, 49, 51].

Vztah mezi pưsobením intruzní síly a apikální resorpcí kořenư je jednoznačný. Intruze je rizikový faktor pro vznik resorpcí kořenů $[5,13,22$, 34, 37, $38,45]$. Protože kořen zubu má přibližně kónický tvar a plocha průřezu klesá směrem $\mathrm{k}$ apexu, dochází ke koncentraci působící síly na malou oblast kořene a to je důvodem, proč zde resorpce vzniká. Linge a Linge [34] uvádějí, že intruze je příčinou největšího množství resorpcí ve srovnání s ostatními druhy pohybu. My jsme v naší studii zjistili při aplikaci intruzní síly $50 \mathrm{cN}$ průměrnou resorpci kořene (RLB) měřenou na CBCT řezech k cemento-sklovinné hranici 0,44 mm a při aplikaci intruzní síly $150 \mathrm{cN} 0,73 \mathrm{~mm}$, obě změny jsou statisticky signifikantní. Podobně velký rozsah intruze jako v naší studii zaznamenali Costopoulos a Nanda [10], kteří k intruzi použili Burstonův intruzní oblouk o intruzní síle $15 \mathrm{cN}$ na zub po dobu 4,6 měsíce. Ve skupině pacientů s Burstonovým obloukem zjistili průměrné zkrácení řezáků $0,6 \mathrm{~mm}$; ve skupině, kde léčba probíhala pomocí kontinuálního oblouku, byla průměrná resorpce $0,2 \mathrm{~mm}$. Mezi těmito hodnotami byl statisticky významný rozdíl. Hofman měřil intruzi po šesti měsících na intraorálních snímcích po použití třídílného intruzního oblouku podle Burstona, Burstonova bazálního oblouku a nivelizace. Prưměrná intruze u třídílného intruzního oblouku byla 0,46 $\mathrm{mm}$, u nivelizace $0,25 \mathrm{~mm}$ a u bazálního oblouku 0,25 $\mathrm{mm}$. Výsledky byly statisticky nesignifikantní [24].

Naproti tomu Dermaut a De Munck [13] se ve své studii zabývali vznikem resorpce po půlroční intruzi 66 horních řezáků v souboru 20 pacientů. Průměrná doba působení intruzní síly velikosti $100 \mathrm{cN}$ na všechny řezáky byla 29 týdnů a během této doby došlo k prưměrnému posunu horních řezákư apikálním směrem o 3,6 mm a došlo k signifikantnímu zkrácení kořenů horních řezáků průměrně o $2,5 \mathrm{~mm}$.

McFadden a kol. [38] studovali resorpce kořenů při použití Rickettsovy bioprogresivní techniky. Na horní a dolní řezáky působili intruzní silou pomocí utility oblouku o velikosti $25 \mathrm{cN}$ na jeden horní řezák. Zaznamenali statisticky signifikantní rozdíl u apikálních resorpcí kořene horních (1,84 mm) a dolních řezáků $(0,61 \mathrm{~mm})$. Nezjistili korelaci mezi zkrácením kořenů a velikostí intruze.

Marek a kol. se ve studii z roku 1999 [37] zaměřili na porovnání resorpčního vlivu různých druhů intruzních systémů. Nejmenší rozsah resorpce horních řezáků zjistili při použití třídílného intruzního oblouku - 0,94 mm. Ve skupině pacientů, u kterých byly intrudovány řezáky bazálním intruzním obloukem, bylo apikální zkrácení kořenư větší, a to 1,75 mm. Dále byli sledováni pacienti s obloukem antiSpee. Zde byla resorpce apexu kořene $1,15 \mathrm{~mm}$ a poslední hodnocenou skupinou byli pacienti s proběhlou nivelizací kontinuálním obloukem, prưměrná resorpce $1,36 \mathrm{~mm}$.

Vztah rozsahu intruze k velikosti resorpce zkoumali Beck a Harrisová [5]. Zjistili, že s větším rozsahem intruzního pohybu stoupá také rozsah resorpce. Výsledky naší studie tyto výsledky nepotvrzují, nezjistili jsme žádný signifikantní vztah mezi rozsahem intruze a velikostí resorpce. 
ČESKÁ STOMATOLOGIE ročník 114, 2014,4

s. $94-102$

Vlivem různé velikosti síly na vznik resorpcí tvrdých zubních tkání během ortodontického pohybu se zabývala řada autorů $[4,7-9,15,17-22,25-28,31$, $33,35,43,46]$. Velikost ortodontické síly se považuje za důležitý faktor pro rychlost a rozsah pohybu a také pro poškození zúčastněných tkání. Některé práce udávají, že příliš velké síly mohou mimo jiné i zvětšit rozsah resorpcí kořenů [4, 9, 17-20, 22, 26-28, $35,46]$. Velikost aplikované síly by měla odpovídat povrchu zubního kořene. Pokud použitá síla přesáhne optimální hladinu pro daný pohyb, dojde k vyšší kompresi periodoncia a ke vzniku ischemie, která může vést k resorpcím kořene. Naproti tomu existují i studie, které prokazují, že rozsah zevních resorpcí kořenů nezávisí na velikosti aplikované síly [8, 15, 18, 35, 43]. Carrilo a kol. [8] zkoumali na vícekořenových zubech u beaglů, jaký vliv má různá velikost intruzní síly na vznik resorpce. Intruzní síla byla vedena spirálkami Sentalloy ke kotevním implantátům, a to 50,100 a $200 \mathrm{cN}$ na zub. Došlo k signifikantní intruzi 1,2 a 3,3 mm. Nebyla prokázána statisticky signifikantní závislost rozsahu intruze na velikosti intruzní síly, i když u síly 100 resp. 200 cN byla velikost intruze mírně větší. Nebyla nalezena žádná závislost mezi velikostí síly a velikostí resorpce. Tato studie tedy dospěla ke stejným závěrům jako naše studie.

Naproti tomu Kurol a kol. [31] zjistili, že resorpce se při ortodontické léčbě vyskytují, i když aplikované síly nedosahují doporučených fyziologických hodnot nutných pro posun zubu. Histologicky prokázali, že po aplikaci síly velikosti $38 \mathrm{cN}$ na první horní premolár mohou po sedmi týdnech vznikat i závažné resorpce.

Dellinger [12] naproti tomu udává, že čím byla menší intruzní síla, tím menší byla resorpce. Zjistil největší resorpci u $300 \mathrm{cN}$, mírnou resorpci při intruzní síle $100 \mathrm{cN}$ a velmi nepatrnou při intruzní síle $10 \mathrm{cN}$ a $50 \mathrm{cN}$, aplikované na první premoláry makaků

Ke stejným histologickým závěrům dospěli Faltin a kol. [17], kteří zjistili větší resorpční lakuny u velkých sil oproti lehkým silám.

Stejným způsobem měřili různé velikosti síly Harrisová a Sims [22]. Byli jedni z prvních, kteří studovali resorpce kořenư pomocí skenovacího elektronového mikroskopu. Uvádějí, že množství resorpčních lakun se zvyšovalo jednak při prodlužování aplikace síly, jednak na základě zvyšování velikosti síly. Tento nárůst však nebyl stejný. Signifikantně více resorpčních lakun vznikalo při prodlužování aplikace síly než při zvyšování velikosti aplikované síly.

Nejnovější práce na toto téma, jako jsou například práce Chana a kol. [26-28], používají také ske- novací elektronový mikroskop a následně pomocí počítačového zpracování získaných dat stanovují hloubku a plochu resorpčních kráterů. Na pět premolárů působili mírnou bukálně vedenou silou $25 \mathrm{cN}$ a na dalších pět premolárů nadměrnou silou $225 \mathrm{cN}$. Zjistili, že nadměrná síla byla příčinou přibližně třikrát většího objemu resorbovaných tvrdých zubních tkání ve srovnání s působením malé síly. Zatímco Chanova práce měřila resorpční lakuny po aplikaci bukální síly, Faltin a kol. [18] vyšetřovali resorpce na povrchu kořenů horních premolárů po působení kontinuálních intruzních sil $50 \mathrm{cN}$ nebo $100 \mathrm{cN}$ po dobu čtyř týdnů. Pomocí transmisního elektronového mikroskopu prokázali na všech intrudovaných zubech jednoznačné známky degenerace buněk, cév, extracelulární matrix cementu a periodontálních ligament. Závažnost těchto změn stoupala ve vztahu $\mathrm{k}$ velikosti aplikované síly.

$\mathrm{K}$ poněkud jiným závěrưm než Chan došli Owman-Moll a kol. [43], kteří se ve svých studiích zabývali taktéž rozdíly $\mathrm{v}$ resorpcích kořenů prvních horních premolárů po sedmitýdenní aplikaci kontinuálních sil různé velikosti v bukálním směru. Nenalezli žádné rozdíly v hloubce ani plošném rozsahu resorpčních lakun při použití síly 50 nebo 100 cN. K rozdílům nedošlo, dokonce ani když sílu zvýšili na 200 cN. Měření rozsahu pohybu premolárů na sádrových modelech ukázalo o 50 \% větší rozsah pohybu po použití síly $200 \mathrm{cN}$ ve srovnání se silou $50 \mathrm{cN}$, což znamená signifikantní rozdíl. Tento rozdíl však nebyl vykoupený signifikantním zvýšením počtu nebo závažnosti zevních resorpcí kořenů. Tento závěr je shodný s výsledky naší práce, nebot' u našich pacientů nedošlo k signifikantnímu zvýšení resorpce apexu kořene při aplikaci vyšší intruzní síly $150 \mathrm{cN}$, ale $k$ většímu rozsahu intruze.

Ani Maltha a Dijkman [35] nezjistili signifikantní vztah mezi zevními resorpcemi kořenů a velikostí aplikované síly. Metodou výzkumu bylo taktéž měření resorpčních lakun na povrchu kořene skenovacím elektronovým mikroskopem.

Jak je patrno z výše uvedených studií, značně propracovanější metoda volumetrického měření resorpčních lakun na povrchu kořene přinesla zvrat v názorech na problematiku velikosti aplikované ortodontické síly jako faktoru ovlivňujícího rozsah resorpce kořene. Zatímco dřívější metody byly odkázané jen na rentgenologická vyšetření, a tím na měření makroskopických zkrácení kořene, výzkumy využívající skenovací elektronový mikroskop umožňují detailní měření velikosti a hloubky resorpčních lakun. V odborných studiích, v nichž se použila výše popsaná metoda, byly zjištěny signifikantně větší (hlubší) resorpční laguny při použití větších sil oproti 
silám malým [4]. Jedinou výjimkou je Malthova studie [35].

Jestliže tuto část diskuse shrneme, zjistíme, že práce, které měřily resorpce apexu kořene mikroskopicky, pomocí skenovacího elektronového mikrosko$\mathrm{pu}$, zjistily závislost velikosti resorpce na velikosti aplikované síly (vyjma studie Malthovy). Ne vždy byla aplikovaná síla silou intruzní, ale výsledky byly jednoznačné. Práce, kde resorpce apexu kořene byly měřeny jen rentgenologicky, měly výsledky různé. Otázkou je, jestli je pro nás klinicky důležité, že vznikají při velké síle hlubší resorpční lakuny, když víme, že ani makroskopicky viditelné resorpce nemají větší klinický význam.

\section{ZÁVĔR}

1. V průběhu aplikace intruzní síly velikosti 50 a 150 $\mathrm{cN}$ došlo $\mathrm{k}$ signifikantnímu zkrácení délky kořenů horních prvních premolárů.

2. Nebyla prokázána závislost apikálních resorpcí kořenů horních premolárů na velikosti aplikované intruzní síly. Rozdíl v resorpci u malé a velké síly byl statisticky nesignifikantní.

3. Velikost resorpce apexu kořene není závislá na rozsahu intruzního pohybu.

4. Větší intruzní síla $150 \mathrm{cN}$ vedla k statisticky signifikantně rozsáhlejší intruzi zubu než při intruzi silou malou $50 \mathrm{cN}$.

5. Nebyl rozdíl mezi resorpcí apexu kořene na vestibulárním a palatinálním kořeni, nezávisle na aplikované intruzní síle.

\section{LITERATURA}

1. Alexander, S. A.: Levels of root resorption associated with continuous arch and sectional arch mechanics. Amer. J. Orthodont. dentofacial Orthop., roč. 110, 1996, č. 3, s. 321-324.

2. Al-Qawasmi, R. A., Hartsfield, Jr. J. K., Everett, E. T., Flury, L., Liu, L., Foroud, T. M., Macri, J. V., Roberts, W. E.: Genetic predisposition to apical root resorption. Amer. J. Orthodont. dentofacial Orthop., roč. 123, 2003, č. 3, s. 242-252.

3. Årtun, J., Smale, I., Behbehani, F., Doppel, D., Van’t Hof, M., Kuijpers-Jagtman, A. M.: Apical root resorption six and 12 months after initiation of fixed orthodontic appliance therapy. Angle Orthodont., roč. 75, 2005, č. 6, s. 919-926.

4. Ballard, D., Chan, E., Petocz, P., Darendeliler, M. A.: Comparison of root resorption after 4 versus 8 weeks of light and heavy forces. Book of abstracts, 83rd Congress EOS, Berlin, 20.-24. 6. 2007.

5. Beck, B. W., Harris, E. F.: Apical root resorption in orthodontically treated subjects: Analysis of edgewise and light wire mechanics. Amer. J. Orthodont. dentofacial Orthop., roč. 105, 1994, č. 4 , s. 350-361.

6. Burstone, C. J., van Steenbergen, E., Hanley, K.: Modern edgewise mechanics and the segmented arch technique. Farmigton, Department of Orthodontics University of Connecticut Health Center, 1995, s. 121.
7. Capan, C., Isik, F., Arun, T.: Tooth movement characteristics with different amounts of forces. Book of abstracts, 81. kongres EOS, Amsterdam, 3.-7. 6. 2005.

8. Carrillo, R., Roossouw, E., Franco, P. F., Opperman, L. A., Buschang, P. H.: Intrusion of multiradicular teeth and related root resorption with mini-screw implant anchorage : A radiographic evaluation. Amer. J. Orthod. dentofacial. Orthop., roč. 132, 2007, č. 5, s. 647-655.

9. Casa, M. A., Faltin, R. M., Faltin, K., Sander, F. G., AranaChavez, V. E.: Root resorptions in upper first premolars after application of continuous torque moment. Intra-individual study. J. Orofac. Orthop., roč. 62, 2001, č. 4, s. 285-295.

10. Costopoulos, G., Nanda, R.: An evaluation of root resorption incident to orthodontic intrusion. Amer. J. Orthodont. dentofacial Orthop., roč. 109, 1996, č. 5, s. 543-548.

11. Dahlberg, G.: Statistical methods for medical and biological students. London: George Allen Unwin, 1940.

12. Dellinger, E. L.: A histologic and cephalometric investigation of premolar intrusion in the Macaca speciosa monkey. Amer. J. Orthodont., roč. 53, 1967, č. 5, s. 325-355.

13. Dermaut, L. R., De Munck, A.: Apical root resorption of upper incisors caused by intrusive tooth movement: A radiographic study. Amer. J. Orthodont. dentofacial Orthop., roč. 90, 1986, č. 4, s. 321-326.

14. DeShields, R. W.: A study of root resorption in treated Clas II Division 1 malocclusion. Angle Orthodont., roč. 39, 1969, s. 231-245.

15. Dorow, C., Sander, F. G.: Development of a model for the simulation of orthodontic load first premolars using the finite element method. J. Orofac. Orthop., roč. 66, 2005, č. 3, s. 208-218.

16. Ericson, S., Kurol, J.: Resorption of incisors after ectopic eruption of maxillary canines: A CT study. Angle Orthodont., roč. 70, 2000, č. 6, s. 415-423.

17. Faltin, R. M., Arana-Chavez, V. E., Faltin, K., Sander, F. G., Wichelhaus, A.: Root resorption in upper first premolar after application of continuous intrusive forces. J. Orofac. Orthop., roč. 59, 1998, č. 4, s. 208-219.

18. Faltin, R. M., Faltin, K., Sander, F. G., Arana-Chavez, V. E.: Ultrastructure of cementum and periodontal ligament after continuous intrusion in humans: a transmission electron microscopy study. Eur. J. Orthodont., roč. 23, 2001, č. 1, s. 35-49.

19. de Freitas, M. R., Beltrao, R. T., Janson, G., Henriques, J. F., Chiquete, K.: Evaluation of root resorption after open bite treatment with and without extractions. Amer. J. Orthod. dentofacial.Orthop., roč. 132, 2007, č. 2, s. 143-144.

20.Gonzales, C., Hotokezaka, H., Yoshimatsu, M., Darendeliler, M. A., Yoshida, N.: Force magnitude and durativ effects on amount of tooth movement and root resorptionin the rat molar. Angle. Orthodont., roč. 78, 2007, č. 3, s. 502-509.

21. Harris, D. A., Jones, A. S., Darendeliler, M. A.: Physical properties of root cementum: Part 8. Volumetric analysis of root resorption craters after application of controlled intrusive light and heavy orthodontic forces: A microcomputed tomography scan study. Amer. J. Orthod. dentofacial. Orthop., roč. 130, 2006, č. 5, s. 639-647.

22. Harry, M. R., Sims, M. R.: Root resorption in bicuspid intrusion: a scanning electromicroscopic study. Angle Orthodont., roč. 52, 1982, č. 3, s. 235-258.

23. Hendrix, I., Carels, C., Kuijpers-Jagtman, A. M., Van`T Hof, M. V.: A radiographic study of posterior apical root resorption in orthodontic patients. Amer. J. Orthodont. dentofacial Orthop., roč. 105, 1994, č. 4, s. 345-349.

24. Hofman, Z.: Resorpce $v$ souvislosti s ortodontickou léčbou. Atestační práce z ortodoncie, 2005 
ČESKÁ STOMATOLOGIE ročník 114 2014, 4

25. Hohmann, A., Wolfram, U., Geiger, M., Boryor, A., Sander, C., Faltin, R., Faltin, K., Sandler, F. G.: Periodontal ligament hydrostatic pressure with areas of root resorption after application of a continuous torque moment. Angle Orthodont., roč. 77, 2007, č. 4, s. 653-659.

26. Chan, E., Darendeliler, M. A., Petocz, P., Jones, A. S.: A new method for volumetric measurement of orthodontically induced root resorption craters. Eur. J. Oral Sci., roč. 112, 2004, č. 2, s. 134-139.

27. Chan, E., Darendeliler, M. A.: Physical properties of root cementum: Part 5. Volumetric analysis of root resorption craters after application of light and heavy orthodontic forces. Amer. J. Orthod. dentofacial. Orthop., roč. 127, 2005, č. 2, s. 186-195.

28. Chan, E., Darendeliler, M. A.: Physical properties of root cementum: Part 7. Extent of root resorption under areas of compression and tension. Amer. J. Orthod. dentofacial. Orthop., roč. 129, 2006, č. 4, s. 504-510.

29. Kamínek, M., Štefková, M.: Ortodoncie II. 1. vydání Olomouc: SPN, 1991, s. 32-39.

30.Kjær, I.: Morphological characteristics of dentitions developing excessive root resorption during orthodontic treatment. Eur. J. Orthodont., roč. 17, 1995, č. 1, s. 25-34.

31. Kurol, J., Owman-Moll, P., Lundgren, D.: Time-related root resorption after application of a controlled continuous orthodontic force. Amer. J. Orthodont. dentofacial Orthop., roč. 110, 1996, č. 3, s. 303-310.

32. Kurol, J., Owman-Moll, P.: Hyalinization and root resorption during early orthodontic tooth movement in adolescents. Angle Orthodont., roč. 68, 1998, č. 2, s. 161-165.

33. Levander, E., Bajka, R., Malmgren, O.: Early radiographic diagnosis of apical root resorption during orthodontic treatment: a study of maxillary incisors. Eur. J. Orthodont., roč. 20, 1998, č. 1, s. 57-63.

34. Linge, B. O., Linge, L.: Apical root resorption in upper anterior teeth. Eur. J. Orthodont., roč. 5, 1983, č. 3, s. 173-183.

35. Maltha, J. C., Dijkman, G. E. H. M.: Discontinuous forces cause less extensive root resorption than continuous forces. Eur. J. Orthodont., roč. 18, 1996, s. 420.

36. Marek, I., Kučera, J., Kamínek, M.: Remodelace kosti alveolárního výběžku během ortodontické intruze s použitím malých a velkých sil. Ortodoncie, roč. 22, 2013, č. 4, s. 211-223.

37. Marek, I., Špidlen, M., Kamínek, M.: Resorpce apexu kořene řezáků III. Vliv typů léčby a rizikové faktory. Ortodoncie, roč. 10, 2001, č. 2, s. 26-33.

38. McFadden, W. M., Engstrom, C., Engstrom, H., Anholm, J. M.: A study of the relationship between incisor intrusion and root shortening. Amer. J. Orthodont. dentofacial Orthop., roč. 96, 1989, č. 5, s. 390-396.

39. McNab, S., Battistutta, D., Taverne, A., Symons, A. L.: Externa apical root resorption following orthodontic treatment. Angle Orthodont., roč. 70, 2000, č. 3, s. 227-232.
40.Mirabella, A. D., Årtun, J.: Risk factors for apical root resorption of maxillary anterior teeth in adult orthodontic patients. Amer. J. Orthodont. dentofacial Orthop., roč. 108, 1995, č. 1, s. 48-55.

41. Murakami, T., Yokota, S., Takahama, Y.: Periodontal ganges after experimentally induced intrusion of the upper incisors in Macaca fuscata monkeys. Amer. J. Orthod. dentofacial Orthop., roč. 95, 1989, č. 2, s. 115-126.

42. Oppenheim, A.: Human tissue response to orthodontic intervention of short and long duration. Amer. J. Orthodont., roč. 28, 1942, s. 263-301.

43. Owman-Moll, P., Kurol, J., Lundgren, D.: The effects of a four-fold increased orthodontic force magnitude on tooth movement and root resorptions. An intra-individual study in adolescents. Eur. J. Orthodont., roč. 18, 1996, č. 3, s. 287-294.

44.Owman-Moll, P., Kurol, J.: The early reparative process of orthodontically induced root resorption in adolescents - location and type of tissue. Eur. J. Orthodont., roč. 20, 1998, č. 6 , S. 727-732

45. Parker, R. J., Harris, E. F.: Directions of orthodontic tooth movements associated with external apical root resorption of the maxillary central incisor. Amer. J. Orthodont. dentofacial Orthop., roč. 114, 1998, č. 6, s. 677-683.

46.Reitan, K.: Initial tissue behavior during apical root resorption. Angle Orthodont., roč. 44, 1974, č. 1, s. 68-82.

47. Reitan, K., Rygh, P.: Biomechanical principles and reactions. In Graber, T. M., Vanarsdall, Jr., R. L.: Orthodontics current principles and techniques. 2nd ed. St. Louis, Mosby - Year Book, 1994, S. 96-192.

48. Ren, Y., Maltha, J. C.: Age effect on orthodontic tooth movement in rats. J. Dent. Res., roč. 82, 2003, s. 38-42.

49.Spence, T. M.: A prospective study of apical root resorption during orthodontic treatment and into retention. Amer. J. Orthodont. dentofacial Orthop., roč. 119, 2001, č. 4, s. A1.

50.VanLoenen, M., dePauw, G., Dermaut, L.: Apical root resorption of upper incisors caused by torque using the tip-edge appliance. Book of abstracts, 81 kongres EOS, Amsterdam, 3.-7. 6. 2005.

51. VonderAhe, G.: Postretention status of maxillary incisors with root-end resorption. Angle Orthodont., roč. 43, 1973, č. 3, s. $247-255$

Prof. MUDr. Milan Kamínek, DrSc. Klinika zubního lékařství LF UP Palackého 12 77200 Olomouc e-mail: kaminek@tunw.upol.cz 